\title{
Determinants of pastoral and agro-pastoral households' participation in fodder production in Makueni and Kajiado Counties, Kenya
}

\author{
Erick Ouma Omollo ${ }^{1 *}$, Oliver Vivian Wasonga ${ }^{1}$, Mohammed Yazan Elhadi ${ }^{1,3}$ and William Ngoyawu Mnene ${ }^{2}$
}

\begin{abstract}
Fodder production has been regarded as one of the suitable strategies for increasing feed availability for enhanced livestock production among pastoral and agro-pastoral communities in the drylands of Kenya. Previous studies indicate that factors determining participation in these practices vary from time to time and from one location to another. This study was conducted to assess the socio-economic and demographic factors influencing households' participation in fodder production in Makueni and Kajiado Counties. Data was collected from 216 households through interviews using semi-structured questionnaire. Results indicate that gender of household head, education, social/development group membership and access to extension services were the most important factors influencing households' participation in fodder production. There is need for technical support to the pastoral and agro-pastoral households towards starting and/or joining existing social groups, through which extension and training services can be offered. This would go a long way in enhancing fodder production in the arid and semi-arid lands of Kenya.
\end{abstract}

Keywords: Demographic, Drylands of Kenya, Factors, Livestock, Socio-economic, Social groups

\section{Introduction}

Livestock production is the main economic activity in the arid and semi-arid lands (ASALs) of Kenya (Kidake et al. 2016) which supports over 14 million people and $70 \%$ of the total country's livestock population (MacOpiyo et al. 2013). A common characteristic of the ASALs is low and erratic precipitation associated with recurrent droughts (Irungu et al. 2014; Gikaba et al. 2014), making poorquality pastures a major constraint to livestock production (Food and Agriculture Organization 2005). Recently, frequent droughts resulting from climate change, population increase and poor land use practices have significantly contributed to degradation and loss of natural pastures (Wasonga 2009; Munyasi et al. 2012; Koech 2014). Consequently, a lot of grazing lands have become bare and/or infested with invasive species (Kidake et al. 2016). As such, natural pasture degradation has been pointed out as the

\footnotetext{
* Correspondence: omolloerick88@gmail.com

1 Department of Land Resource Management and Agricultural Technology, University of Nairobi, P.O. Box 29053-00625, Kangemi, Nairobi, Kenya Full list of author information is available at the end of the article
}

most limiting factor to livestock production in ASALs of Kenya (GoK 2011) with far-reaching effects being low production of milk and meat (Mapiye et al. 2006; Chinogaramombe et al. 2008), thus increasing vulnerability of pastoral livelihoods (Joosten et al. 2014).

Despite these challenges, livestock production still shows a $60 \%$ potential to alleviate ASAL population from poverty (GoK 2005; Irungu et al. 2014). Being the most important requirement for livestock production, availability of high-quality feeds directly reflects success in livestock production (MacOpiyo et al. 2013). Need to increase livestock productivity in the ASALs has led to high demand for better quality feeds, thus calling for better production practices (Gitunu et al. 2003; Manyeki et al. 2015). Fodder production technologies have therefore been introduced by the government of Kenya in the ASALs (Mnene et al. 2004). However, adoption of these technologies is dependent on a number of factors (Wanyama et al. 2003), which vary from region to region and from farmer to farmer (Singh et al. 2012). 
A number of studies have been conducted on factors determining households' participation in fodder production in Kenya. For instance, in their study on factors influencing adoption of fodder production among smallholder farmers in western Kenya, Wanyama et al. (2003) reported that adoption of fodder cropping was limited by lack of quality seed resources, input-output market problems and lack of credit facilities, as well as limited extension services. Although a different study by Irungu et al. (1998) noted that adoption of Napier grass in the highlands of Kenya was influenced by farmer education level, farm size, years of experience in farming and membership in cooperative group, they noticed that accessibility to credit facilities did not have any significant effect on adoption of this particular grass species. Most past studies have reported that prior to adoption of a new idea, farmers learn a great deal on-farm about the performance and suitability of fodder technologies to their farming systems, livestock production practices and its sustainability (Lenné and Wood 2004). In so doing, they learn about the potential benefits and risks that come with the technologies. Therefore, fodder options attuned to farmers' local context are likely to be adopted. Most other studies (Koech 2014; Mureithi et al. 2016; Wairore et al. 2015) have focused mainly on the qualitative and quantitative benefits of fodder production, leaving only grey area on factors determining household participation in fodder production. It is against this background that the current study was conducted to assess factors influencing pastoral and agropastoral households' participation in fodder production in the southern drylands of Kenya. The results of this study are expected to play an important role in enhancing adoption of fodder production technologies through identification of areas that need policy interventions, thus enhancing livestock production for improved and reliable food and livelihood security in the ASALs of Kenya.

\section{Study area}

The study sites were located in Makueni and Kajiado Counties in the ASALs of southern Kenya (Amwata et al. 2015). Makueni County falls between latitude $1^{\circ} 35^{\prime}$ and $30^{\circ} 00^{\prime} \mathrm{S}$ and longitude $37^{\circ} 10^{\prime}$ and $38^{\circ}$ $30^{\prime}$ E with an area of $7965.8 \mathrm{~km}^{2}$. Kajiado County lies between latitude $1^{\circ} 0^{\prime}$ and $3^{\circ} 0^{\prime} \mathrm{S}$ and longitude $36^{\circ} 5^{\prime}$ and $37^{\circ} 5^{\prime} \mathrm{E}$ with an area of $21,901 \mathrm{~km}^{2}$ (CBS 1981; Government of Makueni County 2013; Ogutu et al. 2014) (Figure 1). The study areas were purposively selected because of their active participation in the Agricultural Research Supports Program Phase Two (ARSP-II) that was started in 1998 to develop and disseminate fodder production technologies in the ASALs of Kenya (Mnene et al. 1999; Manyeki et al. 2013). Some of the practices and technologies that were introduced and adopted by the households in these areas include enclosure of natural pastures to allow regeneration, and range reseeding through over-sowing (Manyeki et al. 2015; Kidake et al. 2016). These practices were adopted not only to provide feed for own livestock but also to earn additional income by selling hay and grass seed mainly to local livestock keepers and markets (Mnene 2006; Omollo 2017). Fodder production in the areas is rainfall dependent, with preferred grass species including those that are drought resistant, highly palatable and adapted to the local environments. Some of these grass species include Eragrostis superba, Cenchrus ciliaris, Chloris roxburghiana and Enteropogon macrostachyus (Mnene et al. 1999; Kidake et al. 2016). Also, these grass species are preferred on the basis of their ability to self-reseed and become annual after the first year of establishment. Farmers do not need to prepare land and apply fresh seeds for some years until productivity starts to decline. The main sources of grass seed are the Kenya Agricultural and Livestock Research Organization (KALRO) and farmers' own source - harvesting from naturally growing grass to obtain startup seeds (Omollo et al. 2017). The production is small scale and dependent on own labour and use of locally available and cheap resources such as family labour and ox plough during land preparation and other production activities. The farmers mainly plant grass through seed broadcasting and control weeds by uprooting sprouting unwanted plant (Manyeki et al. 2015; Kidake et al. 2016; Omollo et al. 2017).

These study sites are characterized by highly variable and unpredictable rainfall patterns as well as more severe and extended drought (Gikaba et al. 2014; Amwata et al. 2015). They experience long rains from March to May and short rains from October to December (Gikaba et al. 2014; Amwata et al. 2015), with annual rainfall ranging from 300 to $1250 \mathrm{~mm}$ (Moss 2001; County Government of Makueni 2013). The temperatures in these areas range between 12 and $35{ }^{\circ} \mathrm{C}$ and are influenced by the season and topography (County Government of Makueni 2013; Gikaba et al. 2014).

Kajiado County is dominated by arid to semi-arid grasslands characterized by open grass plains, acacia woodlands, rocky thorn bush lands, swamps and marshlands (Ogutu et al. 2014). The main soils are poorly developed and shallow clayey soils in the floodplains; brown calcareous clay loams, sandy soils, ash and pumice soils in the higher elevations; and basement rock soils which dominate large areas of the County, making pastoralism the only appropriate land use in most parts of the County (Ogutu et al. 2014). In Makueni County the main vegetation includes Commiphora, Accacia and related genera notably of shrubby 


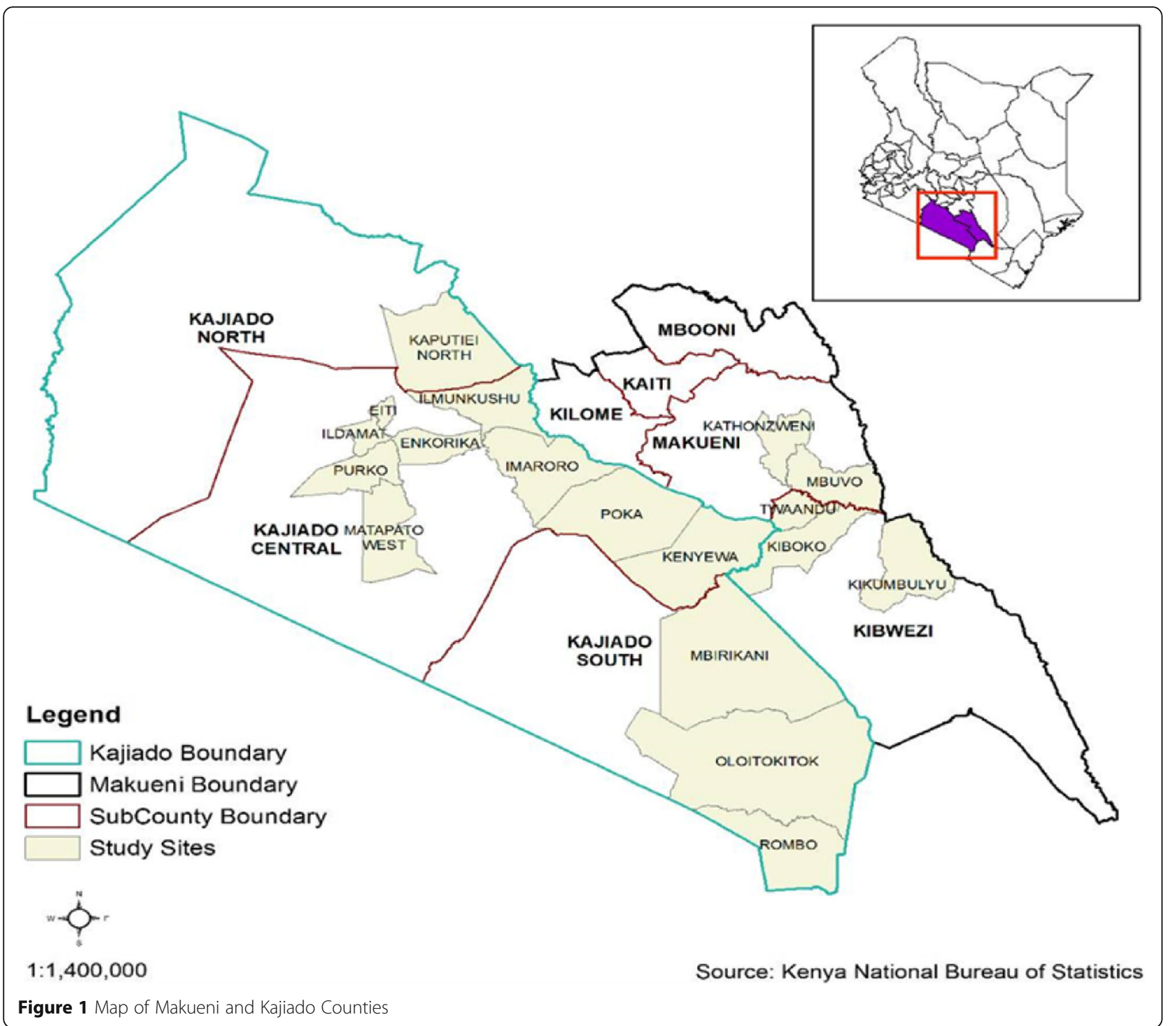

habitat, with dominant grasses being Cenchrus ciliaris, Eragrostis superba, Chloris roxburghiana and Enteropogon macrostachyus (Mganga et al. 2013). The common soils in this area are Ferrasols, Cambisols and Luvisols attributed to strong surface-sealing characteristics that lead to run-offs when heavy rains occur.

Smallholder farming and/or livestock keeping are the most important economic activities in these areas (Amwata et al. 2015). Land tenure and land use in Kajiado County is fast changing with private land ownership quickly replacing the communal ownership system; subdivision and commercialization of communal rangelands to secure legal title to land have also become common. Makueni County has high potential in horticulture and dairy farming especially the hilly parts. The lowlands are used for livestock keeping, cotton and fruit production, and the main fruits grown include mangoes, pawpaw and oranges. The main food crops produced in Makueni are maize, green grams, pigeon peas and sorghum (County Government of Makueni 2013).

\section{Methods}

\section{Sampling design and data collection}

Three sub-counties were purposively selected from each of the two study Counties, based on their active adoption of various fodder production technologies that had been introduced under the ARSP-II program. In Makueni County, the selected sub-counties included Kathonzueni, Makindu and Kibwezi while in Kajiado County, Kajiado Central, Oloitoktok and Mashuru subcounties were selected. Systematic random sampling procedure was used in this study where 36 households were sampled in each of the six sub-counties, resulting 
in selection of 216 households for the interviews. The first household was randomly chosen, and the subsequent respondents were systematically selected after every second household.

The study was preceded by an exploratory survey in each of the six sub-counties under the guidance of the local extension workers, with the view of understanding the context to guide the study approach design and data collection tools. A pre-tested questionnaire was administered to the selected households through face-to-face interviews between June and August 2016; this captured information on socio-economic and demographic characteristics of the respondents. The survey was done with the help of 12 enumerators who had been carefully selected and adequately trained to give them full understanding of the questionnaire and the aim of the study. In addition, 11 focus group discussions with 8 to 12 participants, and 38 key informant interviews were conducted in the study areas in order to get clarification and better understanding of the information gathered from household interviews (Bryman 2008; Mugi-Ngenga et al. 2016). Group participants were knowledgeable people drawn from social or development groups that were also producing fodder within the six sub-counties in the study areas. On the other hand, key informant interview participants included selected individuals producing fodder, extension providers and hay and grass seed traders, as well as the main service providers drawn from government institutions and nongovernmental organizations.

\section{Data analysis}

Descriptive and inferential statistical analyses were done using Statistical Package for Social Science (SPSS) version 22 and STATA version 14. Descriptive statistics including means, standard deviation (SD), frequencies and percentages were generated for the selected socio-demographic characteristics of the sampled households. Binary logistic regression was used to determine factors that influence households' participation in fodder production.

\section{Description of the dependent and hypothesized independent variables}

The dependent variable used in the logit regression model was participation in fodder production. The sample was classified into fodder producers and nonproducers based on the question whether the respondent was producing fodder or not. The value of " 1 " was assigned to fodder producing respondent, while "0" was assigned to a non-participating respondent.

The following independent variables were hypothesized to influence household's participation in fodder production: age, gender and education of household head; size of land owned by household; herd size owned by the household; access to extension services; and membership in social or development group. It was assumed that the independent variables shown in Table 1 simultaneously influenced households' decision to participate or not participate in fodder production technologies, ceteris paribus.

\section{Age of household head}

Age of household head is a key factor that is expected to directly influence availability and access to production and livelihood resources (Wasonga 2009; Lugusa 2015). Access to these resources is an important driving factor in wealth creation and accumulation, thus determining their availability for use by households. At above 35 years of age, household heads are likely to be richer than younger ones, increasing their chances of adopting fodder production technologies. However, studies measuring experience have demonstrated that square of age is negatively associated with uptake of new technologies (Morris and Doss 2001), implying that capacity of a household to adopt new technology is likely to decline after a certain age. Younger farmers/household heads are more risk takers and willing to improve their farming practices by adopting new technologies in order to diversify their livelihoods and increase their income sources, compared to their older counterparts. This study therefore hypothesized that age has a negative relationship with adoption of fodder production. The age of the household head in years was collected and analyzed as a continuous variable.

\section{Gender of household head}

Gender determines access to resources and assets particularly in the rural African context. In the sub-Saharan

Table 1 The variables hypothesized to influence households' participation in fodder production

\begin{tabular}{lll}
\hline Variable & $\begin{array}{l}\text { Description } \\
\text { AGH }\end{array}$ & $\begin{array}{l}\text { Expected influence } \\
\text { on adoption of fodder } \\
\text { production }\end{array}$ \\
GEH & $\begin{array}{l}\text { Age of household head } \\
\text { (number of years) } \\
\text { Gender of the household } \\
\text { head (male }=1, \text { female }=0)\end{array}$ & + \\
EDH & $\begin{array}{l}\text { Education level of the } \\
\text { household head (0= no } \\
\text { education, } 1=\text { primary, }\end{array}$ & + \\
& $\begin{array}{l}2=\text { secondary, } 3=\text { tertiary) } \\
\text { SZL }\end{array}$ & $\begin{array}{l}\text { Size of total land owned } \\
\text { (number of acres) }\end{array}$ \\
GRPM & $\begin{array}{l}\text { Membership in development } \\
\text { group (1 = yes, } 0=\text { no) }\end{array}$ & + \\
SZHRD & $\begin{array}{l}\text { Herd size owned by the } \\
\text { household (total TLU) }\end{array}$ & + \\
ACEXTN & $\begin{array}{l}\text { Access to extension and } \\
\text { training services (1=yes, } \\
0=\text { no) }\end{array}$ \\
\hline
\end{tabular}


Africa, female-headed households have more limited access to productive resources such as livestock, land and finances compared to male-headed households (Adesina et al. 2000). With respect to this, women-headed households are constrained by poor/no access to natural resources (Wasonga 2009). This study therefore hypothesized that male-headed households are more likely to adopt fodder production technologies due to their higher access to key production resources than their female counterparts. Gender of household head was a dummy variable where a value of 1 was assigned to male-headed households and 0 to female-headed households.

\section{Education level of household head}

Education level of household head was measured in terms of number of years spent by the respondent in school. The level of education greatly influences major decision-making in the household. Basically, education creates an opportunity for pastoral and agro-pastoral households to diversify their livelihood sources (Muyanga 2008; Wasonga 2009). More educated household heads are expected to have better reasonability and deeper insight, enabling them to easily understand the benefits of new technologies, hence their adoption (Okello et al. 2009). Education level was therefore expected to have a positive influence on adoption of fodder production technologies. The education level of a household head was assigned the value of 0 if not educated, 1 if attained primary education, 2 for secondary education and 3 for household heads with tertiary education.

\section{Size of land owned}

Total land size owned by households reflects the availability and portion of land that a household can devote for fodder production. Households with larger parcels of land are more likely to set aside some portions of their lands for fodder production, leading to the hypothesis that land size has a positive relationship with participation in fodder production. The size of land owned in acres was treated as continuous variable; the exact values as given by the respondent were used in the analysis.

\section{Membership in a social or development group}

This provides social capital, and helps farmers to pool resources for collective action. Group membership also increases the capacity of members to access services such as credits, extension and information. Participation in such groups is believed to strongly facilitate adoption of new technologies (Salasya et al. 1996). This study hypothesized that membership in a social/development group has a positive influence on adoption of fodder production practices by households. Membership in a social group was a dummy variable where the value 1 was assigned to the households that are members to such groups, while 0 was assigned to the households that are not members of any social groups.

\section{Herd size}

Herd size reflects wealth status of a household in pastoral communities (Wasonga 2009). This study hypothesized that participation in fodder production is dependent on number of livestock a household owns and that there is a positive relationship between the two. Herd size was measured in terms of the total number of livestock owned by a household converted into Tropical Livestock Units (TLUs), where 1 TLU was equated to $250 \mathrm{~kg}$ mature live animal (Kenya Agricultural Research Institute/ODA 1996). In this study, one bull was equivalent to $1.29 \mathrm{TLU}$, a cow $=1 \mathrm{TLU}$, a calf $=0.4 \mathrm{TLU}$ and a sheep or goat $=0.11 \mathrm{TLU}$. Conversion of livestock numbers into TLU equivalent enabled standardization of different animal kinds and classes into a universal unit, thus aiding comparisons between household herds, and was analyzed as continuous variable.

\section{Access to extension and training services}

Provision of extension and training services to farmers is presumed to capacitate households to adopt new technologies. This offers them basic and technical skills and knowledge on fodder production. The current study hypothesized that access to extension and training of fodder production together with sensitization on the importance of the practice positively relates to adoption of fodder production. Access to extension and training services was a dummy variable where a value of 1 was allocated to household heads with access to extension and training services and 0 to household heads with no access.

\section{Specification of the binary logit model}

The model choice of a study is based on the nature of the dependent variable and the objective of the study. The dependent variable in this study was binary that assumed only two values: 1 if the respondent was producing fodder and 0 if otherwise. This kind of variable is normally estimated using logit or probit models, both of which estimate parameters using maximum likelihood approach. While probit model assumes normal distribution error term, the logit model takes a logistic distribution of the error term. This study used the binary logit model due to consistency of parameter estimation associated with the assumption that error term in the equation has a logistic distribution (Baker 2000; Ravallion 2001).

The behavioral model described in the equations below was used to evaluate factors that influence households' participation in fodder production (Gujarati 1995). 


$$
Y_{i}=f\left(t_{i}\right)
$$

This means that there is a functional relationship $(f)$ between the survey observation $\left(Y_{i}\right)$ and the stimuli $t_{\mathrm{i}}$, where,

$$
t=b_{0}+\sum b_{i} X
$$

$Y$ is the response for the $i^{\text {th }}$ observation with binary variable $1=$ producers and $0=$ non-producers. $t_{i}$ is the stimulus index for the $i^{\text {th }}$ observation. It is presumed that there is a threshold index for each household, $t_{i}^{*}$ such that if $t_{i}^{*}>t_{i}^{\text {th }}$ household is observed as a participant in fodder production and if $t_{i}^{*}<t_{i}$, then the household is a non-participant. The probability of such a household participating in fodder farming was computed using Equation 3:

$$
\left\{P_{i}=\left(e^{t i}\right) /\left(1+e^{t i}\right)\right\}
$$

The model for the factors hypothesized to influence households' decision whether to participate in fodder production or not was then re-written as:

$$
Y=\ln \left\{P\left(X_{i}\right) /\left(1-\left(P\left(X_{i}\right)\right\}=\beta_{i} X_{i}+\varepsilon_{\iota}\right.\right.
$$

Where $Y=$ the natural $\log$ of the probability of participating in fodder production $(P)$, divided by the probability of not participating $(1-P)$.

$\beta_{i}=$ coefficient of factors influencing participation in fodder production

$X_{i}=$ factors that are hypothesized to influence participation in fodder production

$\varepsilon_{l}=$ error term

The linear regression model for this study was specified as shown in the Equation 5.

$$
\begin{aligned}
Y= & \beta_{0}-\beta_{1} \mathrm{AGH} \pm \beta_{2} \mathrm{GEH}+\beta_{3} \mathrm{EDH}+\beta_{4} \mathrm{SZL} \\
& +\beta_{5} \mathrm{GRPM}+\beta_{6} \mathrm{SZHRD}+\beta_{7} \mathrm{AGEXTN} \\
& +\varepsilon_{\iota}
\end{aligned}
$$

Several binary logistic regressions were conducted with participation in fodder production as the regress and until the best fit of the model was obtained. The variables that best defined the estimated model were determined based on the coefficient of determination $\left(R^{2}\right)$, adjusted $R^{2}$, chi-square value, the direction of influence of the independent variables, as well as the number of significant variables in the model.

\section{Multicollinearity statistical test: Variance inflation factor}

It was important to ensure that the explanatory variables used in the binary logit model do not correlate with one another, which occurs when two or more independent variables are linearly related (multicollinearity). Multicollinearity usually occurs in all sample data necessitating the need to test the level of its severity in the exogenous explanatory variables (Koustoyiannis 1973). This was done through the test of the variance inflation factor (VIF). Multicollinearity was then eliminated through excluding or merging of some variables during analysis so as to obtain a thrifty model. Long (1997) expression for empirical estimation of VIF was followed:

$$
\mathrm{VIF}=\frac{1}{1-R i^{2}}
$$

where $R_{i}^{2}$ is the $R^{2}$ of the artificial regression with the $i^{\text {th }}$ independent variable as the dependent variable.

\section{Results and discussions}

Results of multicollinearity tests

The VIF of the explanatory variables were found to range from 1.051 to 1.886 with a mean of 1.381 as shown in Table 2. The fact that the VIFs for the independent variables were less than five $(<5)$ provided satisfactorily justification for their inclusion in the logit model (Maddala 2001) as there was no serious problem of multicollinearity.

\section{Socio-demographic characteristics of the sampled households}

Tables 3 and 4 show descriptive statistics of the explanatory variables included in the model. The results showed that in the study areas, fodder producers were significantly $(p<0.01)$ more educated with mean of $9.14 \pm$ 3.99 years of education than non-producers whose mean years of education was $5.80 \pm 4.13$. Households that adopted fodder production had significantly $(p<0.05)$ smaller average land sizes (13.73 \pm 16.81 hectares) than non-producers who had averagely larger land sizes (19.72 \pm 23.29 hectares). The mean age of household head and herd sizes did not have any significant difference between fodder producers and non-producers.

In addition, most (74\%) of fodder producing households were male-headed compared to $55.3 \%$ for non-producing households. Similarly, most (74\%) of the fodder producers

Table 2 Multicollinearity test for the explanatory variables included in the model

\begin{tabular}{lll}
\hline Variable & Tolerance (1/NIF) & VIF \\
\hline Age & 0.776 & 1.288 \\
Gender & 0.951 & 1.051 \\
Education & 0.706 & 1.416 \\
Land size owned & 0.530 & 1.886 \\
Group membership & 0.797 & 1.254 \\
Herd size & 0.724 & 1.381 \\
Access to extension and training & 0.718 & 1.392 \\
Mean VIF & & 1.381 \\
\hline
\end{tabular}


Table 3 Descriptive for the hypothesized variables used in the model

\begin{tabular}{|c|c|c|c|c|c|c|}
\hline \multirow[t]{2}{*}{ Variable } & \multicolumn{2}{|c|}{ Producers $(N=131)$} & \multicolumn{2}{|c|}{ Non-producers $(N=85)$} & \multirow[t]{2}{*}{$t$ value } & \multirow[t]{2}{*}{$p$ value } \\
\hline & Mean & std & Mean & std & & \\
\hline Mean age of the household head (years) & 50.47 & 10.28 & 50.94 & 11.94 & -0.306 & 0.760 \\
\hline Years of education (years) & 9.14 & 3.99 & 5.80 & 4.13 & $5.924^{* * *}$ & 0.000 \\
\hline Total land size (hectares) & 13.73 & 16.81 & 18.72 & 23.29 & $2.339 * *$ & 0.020 \\
\hline Herd size (TLU) & 19.97 & 29.75 & 17.47 & 25.79 & 0.635 & 0.526 \\
\hline
\end{tabular}

Statistical significance level: ${ }^{* * *} 1 \%$ and ${ }^{* *} 5 \%$

were members of certain social groups, compared to only $23.5 \%$ of the non-producing households (Table 4). More (78.6\%) fodder producers had access to extension services than non-producing households (18.8\%). These results indicate that gender, education level, size of land owned, group membership and access to agricultural extension and training services comprise important factors that may influence participation in fodder production among the pastoral and agro-pastoral communities. These findings corroborate those of Irungu et al. (1998) who reported similar factors among others to be primarily important in influencing adoption of agricultural technology.

\section{Results of the binary logit regression}

Table 5 shows the results of the binary logit regression model. Seven variables were tested of which five were statistically significant. The independent variable explains $57 \%\left(R^{2}=0.57\right)$ of the variation in households' participation in fodder production in the study areas. Gender of the households' head had a positive and significant $(p<$ 0.05 ) influence on households' participation in fodder production, implying that male-headed households are more likely to participate in fodder production than those headed by females. This could be attributed to the high labour requirements of these practices which most women may not be able to provide (Manyeki et al. 2015). In addition, women in the traditional context are more engaged with domestic responsibilities, and this is especially true among the communities under study. This limits their access to agricultural information, trainings and extension services (MacOpiyo et al. 2013; GoK 2015; Kidake et al. 2016). The marginal effects show that facilitating both gender participation would increase chances of adopting fodder production technologies by $20 \%$.

Education level of the household heads showed a positively significant $(p<0.05)$ influence on possibility of a households' participation in fodder production, suggesting that households with higher education levels have higher chances of undertaking fodder production, unlike their illiterate or less educated counterparts. Manyeki et al. (2013) reported higher adoption of natural pasture improvement (NaPI) technologies in Makueni and Narok Counties where household heads were more educated than in Mashuru where households were comparatively less educated. Higher education enhances understanding of the value of agricultural technologies and innovations and therefore their adoption (Okello et al. 2009; Oladeebo and Masuku 2013; Asiry et al. 2013).

Participation in a social group and access to extension and training services showed positively significant $(p<0.01)$ influence on households' participation in fodder production. This implies that household heads who participate in groups and with better access to agricultural and extension services were more likely to adopt fodder production. Specifically, the marginal effects explain that an individual's group membership increases their probability of adopting fodder production technologies by $29 \%$, while a unit increase in access to extension and training services increases adoption chances by $49 \%$. This could be linked to the fact that working in organized farmer groups has many benefits such as easier and enhanced access to financial and extension services (Saito et al. 1992; De Haan 2001; Olila, 2014), as well as free or subsidized inputs such as startup grass seeds. Government institutions as well as NGOs have

Table 4 Hypothesized variables used in the model

\begin{tabular}{|c|c|c|c|}
\hline \multirow[t]{2}{*}{ Variable } & & \multicolumn{2}{|l|}{ Frequency (\%) } \\
\hline & & Producers $(N=131)$ & Non-producer $(N=85$ \\
\hline \multirow[t]{2}{*}{ Gender of households head } & Female & $97(74.0)$ & $47(55.3)$ \\
\hline & Male & $34(26.0)$ & $38(44.7)$ \\
\hline \multirow[t]{2}{*}{ Group membership } & Yes & $97(74.0)$ & $20(23.5)$ \\
\hline & No & $34(26.0)$ & $65(76.5)$ \\
\hline \multirow[t]{2}{*}{ Access to extension and training } & Yes & $103(78.6)$ & $16(18.8)$ \\
\hline & No & $28(21.4)$ & $69(81.2)$ \\
\hline
\end{tabular}


Table 5 Logit model estimates for the determinants of household's participation in fodder production

\begin{tabular}{llllll}
\hline Variable & $\beta$ & Wald & Exp $(\beta)$ & Marginal effect & $p$ value \\
\hline Age & $-0.034(0.021)$ & 2.688 & 0.966 & $0.008(0.005)$ & 0.104 \\
Gender & $0.878^{* *}(0.420)$ & 4.367 & 2.407 & $0.976)$ & 0.040 \\
Education & $0.141^{* * *}(0.052)$ & 7.326 & 1.151 & $0.003(0.115)$ & $0.001(0.001)$ \\
Land size owned & $-0.007(0.005)$ & 1.537 & 0.993 & $0.003(0.002)$ & 0.217 \\
Total herd size & $0.015^{* *}(0.008)$ & 2.988 & 1.015 & $0.289(0.085)$ & 0.085 \\
Group membership & $1.318^{* * *}(0.403)$ & 10.699 & 3.736 & $0.492(0.074)$ & -0.001 \\
Access to extension & $2.333^{* * *}(0.414)$ & 31.706 & 10.306 & -0.000 & - \\
Constant & $-1.235(1.340)$ & 0.850 & 0.291 & -
\end{tabular}

Statistical significance level: ${ }^{* *} 1 \%,{ }^{*} 5 \%$; Chi-square $(\mathrm{df}=7)=117.99(p<0.001) ;-2$ log likelihood $=171.577 ;$ Cox and Snell $R^{2}=0.421 ;$ Nagelkerke $R^{2}=0.570$;

$N=216 ;$ standard error in parentheses

successfully implemented many agricultural development programs through working with farmer groups (Weinberger and Jütting 2001). Producer groups in Baringo County have successfully established pasture and rehabilitated degraded lands mainly through the support offered to them by various NGOs such as the Netherlands Development Organization (SNV), Rehabilitation of Arid Environments (RAE) Trust, and Kerio Valley Development Authority (KVDA) (Cooperation for Assistance and Relief Everywhere 2013; Lugusa et al. 2016).

Herd size was found to have positive and significant $(p<0.05)$ relationship with adoption of fodder production, indicating that households with large herds have higher probability of adopting fodder production than those with smaller herds. This is because, under the current situation where there is decline in natural pastures due to climate change and variability, many pastoralists opt to enhance feed availability, as well as quality by adopting various fodder production technologies.

Pastoralist households with large herds but do not produce fodder tend to remain mobile especially in the dry seasons when pasture scarcity greatly limits livestock production. However, the challenge of diminishing communal grazing fields due to subdivision of rangelands into private parcels has threatened the viability of mobility as survival strategy (Africa Development Bank Group (AfDB) 2010). This can be regarded as an impulsive force leading to establishment of fodder by livestock keepers with larger herds.

\section{Conclusions}

The results of this study indicate that gender, group membership and access to extension and training services are the most important factors that encourage and promote households' participation in fodder production. Household heads that have access to extension services and are also members of social groups are more likely to adopt fodder production. This is due to the fact that extension workers and other supporting organization prefer to reach out to farmers through their organized social groups. Efforts towards out-scaling fodder production should target access to extension and training services and support households to start and/or join existing social groups, which are known to be avenues for accessing extension and training services with the ultimate goal of ensuring sustainable and efficient fodder production in the drylands of Kenya.

\section{Acknowledgements}

The authors thank the Regional Universities Forum for Capacity Building in Agriculture (RUFORUM) for funding and the University of Nairobi and the Kenya Agricultural and Livestock Research Organization for their support in facilitation. We also thank the fodder producers and other individuals in Makueni and Kajiado Counties for providing information for this study.

\section{Authors' contributions}

EOO contributed by developing the concept and designing the study, collected the data, carried out analysis and interpretation of data, drafted the manuscript and submitted to this journal after approval by the supervisors. OVW, MEY and WNM contributed to the conception and design of the study, provided technical and intellectual support during analysis and interpretation of the data and drafted this manuscript. They too facilitated the acquisition of funds for the study. All authors read and approved the final manuscript.

\section{Competing interests}

The authors declare that they have no competing interests.

\section{Publisher's Note}

Springer Nature remains neutral with regard to jurisdictional claims in published maps and institutional affiliations.

\section{Author details}

${ }^{1}$ Department of Land Resource Management and Agricultural Technology, University of Nairobi, P.O. Box 29053-00625, Kangemi, Nairobi, Kenya. ${ }^{2}$ Kiboko Research Centre, Kenya Agricultural and Livestock Research Organization (KALRO), P.O.Box 12-90138, Makindu, Kenya. ${ }^{3}$ Adaptation (ADA) Consortium, National Drought Management Authority, P.O. Box 74247, Nairobi 00200, Kenya.

Received: 25 September 2017 Accepted: 10 January 2018 Published online: 14 March 2018

\section{References}

Adesina, A.A., D. Mbila, G.B. Nkamleu, and D. Endamana. 2000. Econometric analysis of the determinants of adoption of alley farming by farmers in the forest zone of southwest Cameroon. Agriculture, Ecosystems \& Environment 80 (3): 255-265.

Africa Development Bank Group (AfDB). 2010. Regional study on the sustainable livestock development in the Greater Horn of Africa: Main synthesis report. Volume I. pp. 41-48. Log Associates, Nairobi Kenya. Retrieved from: https:// www.afdb.org/fileadmin/uploads/afdb/Documents/Project-and-Operations/ 
Final_Synthesis_Report_AfDB_Regional_Livestock_Study_20_January_ 2010\%5B1\%5D.pdf. Accessed 13 Feb 2016.

Amwata, D.A., D.M. Nyariki, and N.R. Musimba. 2015. Factors influencing pastoral and agro-pastoral household vulnerability to food insecurity in the drylands of Kenya: A case study of Kajiado and Makueni Counties. Journal of International Development 28 (5): 771-787.

Asiry, K.A., S.S.M. Hassan, and M.M. AlRashidi. 2013. Factors affecting agricultural sustainability - a case study of Hail Region, Kingdom of Saudi Arabia. Asian Journal of Agriculture and Rural Development 3 (10): 674

Baker, J.L. 2000. Evaluating the impact of development projects on poverty: A handbook for practitioners. New York: World Bank Publications.

Bryman, A. 2008. Social research methods. third ed. Oxford: Oxford University Press.

Central Bureau of Statistics (CBS). 1981. The 1979 population census. Ministry of Finance and Planning. Government Printer: Nairobi.

Chinogaramombe, G., Muchenje, V., Mapiye, C., Ndlovu, T., Chimonyo, M., and Musemwa, L. 2008. Challenges for improving smallholder dairy production in the semiarid areas of Zimbabwe. Livestock Research for Rural Development. Volume 20, Article no. 34. Retrieved August 12, 2016, from http://www.Irrd.org//rrd20/3/chin20034.htm

Cooperation for Assistance and Relief Everywhere (CARE). 2013. Embracing fodder farming in northern Kenya. Available at: https://www.care.or.ke/index. php/2-uncategorised/184-embracing-fodder-farming-in-northern-kenya. Accessed 4 June 2017.

De Haan, N. 2001. Of goats and groups: A study on social capital in development projects. Agriculture and Human Values 18 (1): 71-84.

Doss, C. R., and Morris, M. L. 2001. How does gender affect the adoption of agricultural innovations?: The case of improved maize technology in Ghana. Agricultural Economics 25 (1), 27-39.

Food and Agriculture Organization. 2005. EASYPol. On-line resource materials for policymaking. Analytical tools. Module 043.Commodity chain analysis. Constructing the commodity chain, functional analysis and flow charts in Faße, A., Grote, U., and Winter, E. (2009). Value chain analysis methodologies in the context of environment and trade research (No. 429). Discussion papers// School of Economics and Management ofthe Hanover Leibniz University.

Gikaba, J.M., K.S. Muthoni, and B.O. Bebe. 2014. Influence of drought duration on livestock feeding practices by Maasai pastoralists in Kajiado County, Kenya. International Journal of Innovation and Applied Studies 8 (1): 225-231.

Gitunu, AMM, Mnene WN, Muthiani EN, Mwacharo JM, Ireri R, Ogillo B, and Karimi SK. 2003. Increasing the productivity of livestock and natural resources in semi-arid areas of Kenya: A case study from the southern Kenyan rangelands. In: Agricultural Research and Development for Sustainable Resource Management and Food Security in Kenya. Proceedings of the $6^{\text {th }}$ KARI End of EU Programme Conference held on November 11-12 November 2003 at KARI Headquarters, Nairobi.

Government of Kenya (GoK). 2005. National Policy for the Sustainable Development of Arid and Semi-arid Lands of Kenya. Nairobi; Government press.

Government of Kenya (GoK). 2011. Vision 2030 development strategy for northern Kenya and other arid lands. Nairobi, Kenya. Accessed 12 Mar 2017 from: http://www.fao.org/fileadmin/user_upload/drought/docs/ Vision2030\%20development\%20strategy\%20for\%20northern\%20kenya\% 20and\%20other\%20dry\%20areas\%202011\%20.pdf.

Government of Kenya (GoK) 2015. National Policy for the Sustainable Development of Northern Kenya and other Arid Land (draft). Ministry of Devolution and Planning, GoK.

Government of Makueni County. First integrated development. 2013. 2013-2017.

Gujarati, D.N. 1995. Basic econometrics. 4th ed, 100-343. New York: MacGraw-Hill, Inc.

Irungu, P., P. Ithondeka, E. Wafula, S. Wekesa, H. Wesonga, and T. Manga. 2014. An audit of constraints and opportunities in Kenya's livestock export value chain. Journal of Agricultural Science and Technology B4 (2014): 102-120.

Irungu, P., Mbogo, S., Staal, S., Thorpe, W. and Njubi, D. 1998. Kenya Agricultural Research Institute. Factors influencing adoption of Napier grass in smallholder dairy farming in highlands of Kenya. Agricultural Research and Development for Sustainable Resource Management and Increased Production. Proceedings of the 6th Bi-annual KARI Scientific Conference. 294-301.

Joosten, K., Ekodere, P., and Miano, G. 2014. Best practice brief - fodder production in Baringo County. Article available at: http://asalsmarkets. wikispaces.com/file/view/Best+practice+brief++Mayiani+fodder+group+(2). pdf. Accessed 13 Mar 2017.
Kenya Agricultural Research Institute/ODA. 1996. Manual of livestock production systems in Kenya. Livestock Socio Economics and Epidemiology Project. Kikuyu: National Veterinary Research Centre.

Kidake, B. K., Manyeki, J. K., Kubasu, D., and Mnene, W. N. 2016. Promotion of range pasture and fodder production among the pastoral and agropastoral communities in Kenyan rangelands: Experiences and lessons learnt. Livestock Research for Rural Development, Volume 28. Retrieved from: http://www.Irrd. org/lrrd28/8/kida28151.html. Accessed 21 Mar 2017.

Koech, O. K., 2014. Comparative evaluation of six indigenous rangeland grasses for pasture production under varying soil moisture contents in Tana River County, South Eastern Kenya. PhD Thesis, University of Nairobi.

Koustoyiannis, A. 1973. Theory of econometrics. Macmillan Press Ltd..

Lenné, J.M., and D. Wood. 2004. Is there a 'logic of fodder legumes' in Africa? Food Policy 29 (5): 565-585.

Long, J. 1997. Regression models for categorical and limited dependent variables. Thousand Oaks: Sage Publications.

Lugusa, K. 2015. Fodder production as an adaptation strategy in the drylands: A case study of producer groups in Baringo County, Kenya. MSc. Thesis, University of Nairobi.

Lugusa, K.O., O.V. Wasonga, Y.A. Elhadi, and T.A. Crane. 2016. Value chain analysis of grass seeds in the drylands of Baringo County, Kenya: A producers' perspective. Pastoralism 6 (1): 6.

MacOpiyo, L, Irungu, P, Elhadi, YM. 2013. Study of livestock, fodder, milk production and marketing in arid and semi-arid lands of Kenya under-promotion and strengthening enterprises and market systems in drought-prone ASAL areas. Baseline report For Kajiado, West Pokot And Narok Counties.

Maddala, G. S. 2001. Introduction to econometrics, 3rd edition. Wiley and Sons Inc, 32.

Manyeki, J.K., E.C. Kirwa, P.B. Ogillo, W.N. Mnene, R. Kimitei, A. Mosu, and R. Ngetich. 2015. Economic analysis of natural pasture rehabilitation through reseeding in the southern rangelands of Kenya. Livestock Res. for Rural Development 27 (3): 49-61.

Manyeki, J. K., Kubasu, D., Kirwa, E. C., and Mnene, W. N. 2013. Assessment of socio-economic factors influencing adoption of natural pastures improvement technologies in arid and semi-arid lands of Kenya. Livestock Research for Rural Development 25 (11) 2013.

Mapiye, C., Foti, R., Chikumba, N., Poshiwa, X., Mwale, M., Chivuraise, C., and Mupangwa, J. F. 2006. Constraints to adoption of forage and browse legumes by smallholder dairy farmers in Zimbabwe. Livestock Research for Rural Development, 18(12), 2006.

Mganga, Z.K. N.K.R. Musimba, D.K. Nyariki, et al. 2013. The choice of grass species to combat desertification in semi-arid Kenyan rangelands is greatly influenced by their forage value for livestock. Grass and Forage Science 70: 161-116.

Mnene, W. N. 2006. Strategies to increase success rates in natural pasture development through reseeding degraded rangelands of Kenya. PhD Thesis, University of Nairobi, Nairobi, Kenya.

Mnene, W. N., Muthiani, E. N., Ndung'U, J. N., Manyeki, J. K., and Ndathi, A. JN. 2004. Assessment of possible activities for increased resilience of agropastoral and pastoral communities to crises in southern Kenya. Kenya Agricultural Research Institute (KARI)/ ASARECA Animal Agricultural Research Network (A-AARNet) Workshop Report.

Mnene, W. N., Wandera, F. P., and Lebbie, S. H. 1999. Arresting environmental degradation through accelerated on-site soil sedimentation and revegetation using micro-catchments and reseeding. In: Proc. Agricultural Research and Development for sustainable Resource Management and Increased Production. $6^{\text {th }}$ KARI Scientific Conference, 9-13 $3^{\text {th }}$ November 1998. Nairobi.

Moss, C.J. 2001. The demography of an African elephant (Loxodonta africana) population in Amboseli, Kenya. Journal of Zoology 255: 145-156.

Mugi-Ngenga, E.W., M.W. Mucheru-Muna, J.N. Mugwe, F.K. Ngetich, F.S. Mairura, and D.N. Mugendi. 2016. Household's socio-economic factors influencing the level of adaptation to climate variability in the dry zones of Eastern Kenya. Journal of Rural Studies 43: 49-60.

Munyasi, J.W., A.M.M. Gitunu, J.K. Manyeki, E.N. Muthiani, and S.O. Nyamwaro. 2012. Non-traditional land-use practices in the pastoral Maasai region in Loitokitok district of Kajiado county, Kenya. Journal of Agricultural Extension and Rural Development 4 (16): 428-434.

Mureithi, S. M., Verdoodt, A., Njoka, J. T., Gachene, C. K., \& Van Ranst, E. (2016), Benefits derived from rehabilitating a degraded semi-arid rangeland in communal enclosures, Kenya. Land Degradation \& Development, 27(8), 1853-1862.

Muyanga, M. 2008. Household vulnerability to transient and chronic poverty: Evidence from rural Kenya. In Ninth Annual Conference of Global Development Network (GDN), 29-31. 
Ogutu, J.O., H.P. Piepho, M.Y. Said, and S.C. Kifugo. 2014. Herbivore dynamics and range contraction in Kajiado County Kenya: Climate and land use changes, population pressures, governance, policy and human-wildlife conflicts. Open Ecology Journal 7: 9-31.

Okello, J. J., Okello, R. M., and Ofwona-Adera, E. 2009. Awareness and the use of mobile phones for market linkage by smallholder farmers in Kenya. Eagriculture and e-government for global policy development, 1-18. https:// books.google.com/books?hl=en\&lr=\&id=mPUgbEO-kYsC\&oi=fnd\&pg= PA1\&dq=Okello,+J.+J.,+Okello,+R.+M.,+and+Ofwona-Adera,+E.+2009.+ Awareness+and+the+use+of+mobile+phones+for+market+linkage+by +smallholder+farmers+in+Kenya.+E-agriculture+and+e-government+for +global+policy+development,+1-18.\&ots=t3e9l_gSVr\&sig= 226orzacFMsEQOs6-3eTrWpBCgQ.

Oladeebo, J.O., and M.B. Masuku. 2013. Effect of farmer education and managerial ability on food crop production in Nigeria. Journal of Economics and Sustainable Development 4 (7): 75-82.

Olila, D.O. 2014. Economic evaluation of factors affecting farmers participation in development groups: A case of Trans-Nzoia County, Kenya. Journal of Agricultural Economics, Extension and Rural Development 2 (6): 074-081.

Omollo E. O. 2017. Analysis of fodder production and marketing in the southern rangelands of Kenya. MSc. Thesis, University of Nairobi.

Omollo, E. O., Wasonga, O. V., Elhadi YAM, and Mnene, W. N. 2017. Grass seed value chain analysis in the Southern Kenya range lands of Makueni and Kajiado Counties. Conference paper. RUFORUM Working Document Series (ISSN 1607-9345) No. 14(2): 645-651. Retrieved from: http://repository. ruforum.org/documents/grass-seed-value-chain-analysis-southern-kenyarange-lands-makueni-and-kajiado-counties. Accessed 10 Oct 2017.

Ravallion, M. 2001. The mystery of the vanishing benefits: An introduction to impact evaluation. The World Bank Economic Review 15 (1): 115-140.

Saito, K. A., Southgate, D. S., Molinos, R., Guerrón, V., BF Kernan, Sheng, T. C. and Guhl, N. E. 1992. Developing agricultural extension for women farmers (No. GTZ-789). Banco Mundial, Washington, DC (EUA).

Salasya, B., Odendo, M., and Odenya, J. 1996. Adoption of improved sorghum varieties and other production technologies in Busia District Kenya. In Proceedings of the 5th KARI Scientific Conference. Kenya Agricultural Research Institute (KARI), Nairobi Kenya.

Singh, K. M., Meena, M. S., and Kumar, A. 2012. An economic view to forage and fodder production in Eastern India. https://ssrn.com/abstract=2030697.

Wairore, J.N., S.M. Mureithi, O.V. Wasonga, and G. Nyberg. 2015. Enclosing the commons: Reasons for the adoption and adaptation of enclosures in the arid and semi-arid rangelands of Chepareria, Kenya. SpringerPlus 4 (1): 595.

Wanyama, J. M., Muyekho, F., Masinde, A. O., Cheruiyot, D. T., Odongo, J., Ojowi, M. and Okeyo, R. 2003. Assessing factors influencing adoption of pastures and fodders amongst smallholder subsistence farmers in selected districts of west Kenya. Tropical Grasslands 37: 219-226.

Wasonga, V. O. 2009. Linkages between land-use, land degradation and poverty in semi-arid rangelands of Kenya: The case of Baringo district (Doctoral dissertation, University of Nairobi, Department of agriculture).

Weinberger, K, and J.P. Jütting. 2001. Women's participation in local organizations: Conditions and constraints. World Development 29 (8): 1391-1404.

\section{Submit your manuscript to a SpringerOpen ${ }^{\circ}$ journal and benefit from:}

- Convenient online submission

- Rigorous peer review

- Open access: articles freely available online

- High visibility within the field

- Retaining the copyright to your article

Submit your next manuscript at $\gg$ springeropen.com 